\title{
Point prevalence study of antibiotic susceptibility of genital group B streptococcus isolated from near-term pregnant women in Calgary, Alberta
}

\author{
Deirdre Church MD PhD FRCPC ${ }^{1,2,3}$, Julie Carson MD FRCPC ${ }^{1,2}$, Dan Gregson MD FRCPC $1,2,3$
}

\begin{abstract}
D Church, J Carson, D Gregson. Point prevalence study of antibiotic susceptibility of genital group B streptococcus isolated from near-term pregnant women in Calgary, Alberta. Can J Infect Dis Med Microbiol 2012;23(3):121-124.
\end{abstract}

BACKGROUND: Genital group B streptococcus (GBS) may be transmitted from a colonized mother to her infant if appropriate intrapartum antibiotic prophylaxis is not given. A recent case of GBS neonatal sepsis occurred due to an erythromycin-intermediate strain after empirical use of this drug as intrapartum prophylaxis.

OBJECTIVE: To determine the regional antibiotic resistance rates of genital GBS isolates to penicillin, erythromycin and clindamycin.

METHODS: A total of 309 genital GBS strains cultured from vaginal/ rectal swabs were prospectively isolated and randomly selected between March and May 2011. Etest strips (bioMèrieux, France) were used to determine the minimum inhibitory concentrations to penicillin, erythromycin and clindamycin according to standard methods. All isolates that either demonstrated intermediate or full resistance to erythromycin had a D-test performed to detect inducible resistance to clindamycin. The resistance mechanism for each isolate was inferred from its antibiogram phenotype.

RESULTS: All genital GBS isolates were susceptible to penicillin, but high rates of resistance were found to both erythromycin (25\%) and clindamycin (22\%), mainly due to acquisition of erythromycin ribosomal methylation genes (erm) that result in the $\mathrm{MLS}_{\mathrm{B}}$ resistance phenotype. Most often the $\mathrm{MLS}_{\mathrm{B}}$ resistance phenotype was constitutive $\left(\mathrm{MLS}_{B}-\mathrm{C} ; 14.2 \%\right)$ rather than inducible $\left(\mathrm{MLS}_{\mathrm{B}}-\mathrm{I} ; 8.1 \%\right)$, and an efflux mechanism $(\mathrm{msrA} ; 3 \%)$ was much less common.

DISCUSSION: The present article is the first point prevalence study of genital GBS antibiogram profile that has been reported from a Canadian health care region. The high rates of resistance of genital GBS to both erythromycin and clindamycin is mainly due to the acquisition and spread of erm genes conveying the $\mathrm{MSL}_{\mathrm{B}}$ phenotype. CONCLUSION: Changes to clinical and laboratory practice in the Calgary, Alberta, region were made to prevent additional cases of neonatal GBS sepsis due to inappropriate intrapartum antibiotic prescription.

Key Words: Antibiotic resistance; Group B streptococcus; Neonatal sepsis

\author{
Une étude de prévalence ponctuelle sur la \\ susceptibilité aux antibiotiques du streptocoque du \\ groupe B génital isolé chez des femmes enceintes \\ presque à terme de Calgary, en Alberta
}

\begin{abstract}
HISTORIQUE : En l'absence de prophylaxie antibiotique intrapartum, le streptocoque du groupe $B$ (SGB) génital peut être transmis d'une mère colonisée à son nourrisson. Un récent cas de sepsie à SGB néonatal s'est produit en raison d'une souche intermédiaire à l'érythromycine après l'utilisation empirique de ce médicament en guise de prophylaxie intrapartum. OBJECTIF : Déterminer le taux régional de résistance des isolats de SGB génital à la pénicilline, à l'érythromycine et à la clindamycine.

MÉTHODOLOGIE : Au total, les chercheurs ont isolé et sélectionné au hasard 309 souches de SGB génital provenant de cultures d'écouvillons vaginaux ou rectaux entre mars et mai 2011. Ils ont utilisé des bandes de test $\mathrm{E}$ (bioMèrieux, France) pour déterminer les concentrations inhibitrices minimales à la pénicilline, à l'érythromycine et à la clindamycine, conformément aux méthodes classiques. Pour tous les isolats qui démontraient une résistance intermédiaire ou complète à l'érythromycine, ils ont effectué un test $\mathrm{D}$ afin de déceler la résistance inductible à la clindamycine. Ils ont inféré le mécanisme de résistance de chaque isolat à partir du phénotype de l'antibiogramme.

RÉSULTATS : Tous les isolats de SGB génital étaient susceptibles à la pénicilline, mais les chercheurs ont observé de forts taux de résistance à la fois à l'érythromycine (25\%) et à la clindamycine (22\%), surtout en raison de l'acquisition de gènes de méthylation ribosomique à l'érythromycine (erm), qui provoquent le phénotype de résistance aux MLSB. La plupart du temps, le phénotype de résistance aux MLSB était d'ordre constitutif (MLSB-C; 14,2 \%) plutôt que d'ordre inductible (MLSB-I; 8,1 \%). Le mécanisme d'efflux ( $m s r A ; 3 \%$ ) était beaucoup moins courant.

EXPOSÉ : Le présent article est la première étude de prévalence ponctuelle sur le profil antibiogramme du SGB génital provenant d'une région sanitaire canadienne. Les taux élevés de résistance du SGB génital à l'érythromycine et à la clindamycine sont surtout causés par l'acquisition et la propagation des gènes conférant une résistance aux macrolides (erm) transportant le phénotype aux MSLB.

CONCLUSION : Des changements à la pratique clinique et de laboratoire ont été apportés dans la région de Calgary, en Alberta, afin d'éviter de nouveaux cas de sepsie à SGB néonatal attribuables à une prescription inadéquate d'antibiotiques pendant la période intrapartum.
\end{abstract}

thereby preventing early onset disease $(1,10,11)$. Several agencies/ societies and studies $(1,12)$ have published consensus guidelines for the prevention of early-onset neonatal GBS disease that recommend universal prenatal testing of pregnant women for vaginal/rectal colonization near term (ie, 35 to 37 weeks of gestation or sooner if membrane rupture occurs), with intrapartum chemoprophylaxis offered to the carriers. Laboratory detection of GBS colonization in near-term pregnant women is, therefore, critically important so that appropriate

antibiotic prophylaxis can be prescribed at delivery. roup B streptococcus (GBS) is the most common cause of early

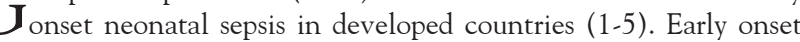
disease (zero to six days of life) is acquired intrapartum from mothers with vaginal/rectal colonization with GBS $(1,5,6)$. Maternal GBS colonization rates range from approximately $10 \%$ to $40 \%$ in developed countries, with an estimated rate of $20 \%$ in near-term pregnant women in our Canadian health region (Calgary, Alberta) (3,4,6-9). Studies have shown that selective intrapartum administration of antibiotics to colonized women reduces neonatal transmission of GBS,

${ }^{1}$ Division of Microbiology, Calgary Laboratory Services; ${ }^{2}$ Department of Pathology $\mathcal{G}$ Laboratory Medicine; ${ }^{3}$ Department of Medicine, Faculty of Medicine, University of Calgary, Calgary, Alberta

Correspondence: Dr Deirdre Church, Calgary Laboratory Services, 9-3535 Research Road Northwest, Calgary, Alberta T2L 2K8.

Telephone 403-770-3281, fax 403-770-3347, e-mail deirdre.church@cls.ab.ca 
TABLE 1

Genital group B streptococcus antibiogram profile for Calgary, Alberta (2011)

\begin{tabular}{|c|c|c|c|c|}
\hline Antibiotic & $\begin{array}{c}\text { \% Susceptible, } \\
\quad(n=309)\end{array}$ & $\begin{array}{c}\text { \% Resistant, } \\
(n=309)\end{array}$ & $\begin{array}{l}\text { Resistance } \\
\text { mechanism }\end{array}$ & Total, $\%$ \\
\hline Penicillin & 100 & None & N/A & $\mathrm{N} / \mathrm{A}$ \\
\hline \multirow[t]{3}{*}{ Erythromycin } & 75 & 25 & Efflux & 3 \\
\hline & & & $\mathrm{MLS}_{\mathrm{B}}{ }^{-1}$ & 8.1 \\
\hline & & & $\mathrm{MLS}_{\mathrm{B}}-\mathrm{C}$ & 14.2 \\
\hline \multirow{2}{*}{$\begin{array}{l}\text { Inducible ribosomal } \\
\text { methylation } \\
\text { (Clindamycin) }\end{array}$} & 78 & 22 & $\mathrm{MLS}_{\mathrm{B}}{ }^{-1}$ & 8.1 \\
\hline & & & $\mathrm{MLS}_{\mathrm{B}}-\mathrm{C}$ & 14.2 \\
\hline
\end{tabular}

${ }^{*}$ Based on the phenotypic antibiotic susceptibility profile. Efflux msrA (erythromycin resistant [R], clindamycin sensitive [D-test negative]); $M L S_{B}{ }^{-C}$ Ribosomal methylation (constitutive) (erythromycin R, clindamycin R); $M L S_{B}{ }^{-l}$ Ribosomal methylation (inducible) (erythromycin $R$, clindamycin $R$ [D-test positive]); N/A Not applicable

Our clinical microbiology laboratory performs routine isolation of GBS from vaginal/rectal swabs, but antibiotic susceptibility testing is not routinely performed unless the physician indicates that the patient has a penicillin allergy or specifically requests this testing be performed. This practice is consistent with current guidelines for antibiotic susceptibility testing of genital GBS isolates that is followed by clinical microbiology laboratories in Canada and the United States (13), based on the premise that genital GBS remain almost universally susceptible to penicillin and other $\beta$-lactam drugs that are prescribed to women without allergy. Canadian guidelines have not been recently updated and continue to recommend the use of erythromycin and clindamycin as alternative antibiotic agents in women colonized with genital GBS who have a penicillin allergy (12).

However, our experience with a recent case of early onset neonatal GBS bacteremia, and the subsequent results of a regional point prevalence study of genital GBS isolate antibiotic susceptibility profiles, highlights the need for changes to laboratory and clinical practice in this regard.

\section{CASE PRESENTATION}

A near-term pregnant woman had a vaginal/rectal swab collected for GBS culture. The patient was confirmed to be colonized with GBS, but antibiotic susceptibility testing was not performed because the physician had not made this request nor was there an indication of penicillin allergy on the laboratory requisition. A second vaginal/rectal swab was collected two weeks later, and the physician requested that antibiotic susceptibility testing be performed due to the patient's penicillin allergy. The patient went into labour and delivered before the testing was complete. Following the Canadian guideline for penicillin-allergic patients (12), she was prescribed prophylaxis with intravenous erythromycin in the recommended dose of $500 \mathrm{mg}$. The infant developed GBS bacteremia three days after delivery. Both the maternal genital and neonatal blood GBS isolates had the same antibiogram profile, with a penicillin Etest (bioMèrieux, France) minimum inhibitory concentration of $0.047 \mu \mathrm{g} / \mathrm{mL}$, which is sensitive, a Kirby-Bauer zone size of $25 \mathrm{~mm}$ for clindamycin, which is sensitive, but a zone size of $17 \mathrm{~mm}$ for erythromycin, which is intermediate. Both the maternal genital and neonatal blood GBS isolates did not produce a D-zone, indicating that these strains had a phenotype consistent with an efflux mechanism of resistance (ie, erythromycin [intermediate or resistant], clindamycin [sensitive] and a negative D-zone). Subsequently, a clinical and laboratory incident review of this case was performed to implement measures that would prevent a repeat of this serious occurrence.

\section{METHODS}

Laboratory confirmation of GBS colonization requires collection of a vaginal/rectal swab. Calgary Laboratory Services performs approximately 15,000 vaginal/rectal swab cultures per year using culture-based detection for genital group B streptococcus that includes the use of a selective broth as previously described (14). Vaginal/rectal swabs are physician collected using Copan swabs (Copan Italia SPA, Italy) in liquid Amies transport tubes, and transported within $4 \mathrm{~h}$ to $6 \mathrm{~h}$ to the laboratory. Swabs are inoculated into StrepB Carrot Broth (SCB, Hardy Diagnostics Inc, USA) on receipt and incubated for $18 \mathrm{~h}$ to $24 \mathrm{~h}$ at $35^{\circ} \mathrm{C}$. All SCB cultures were read as positive if a visible colour change, from colourless to orange or red, occurred. Samples negative by SCB culture were subsequently subcultured onto $5 \%$ sheep blood agar, incubated for an addtional $18 \mathrm{~h}$ to $24 \mathrm{~h}$ at $35^{\circ} \mathrm{C}$ and analyzed for the presence of GBS using standard biochemical methods. Genital GBS isolates recovered from pregnant women with a reported penicillin allergy are routinely tested for antibiotic susceptibility to penicillin by Etest, and the Kirby-Bauer disk method for clindamycin and erythromycin. All isolates that demonstrate intermediate or full resistance to erythromycin have a D-test performed to determine inducible resistance to clindamycin $(13,15)$.

Antibiotic susceptibility testing was performed on a total of 309 genital GBS isolates that were prospectively isolated and randomly selected from vaginal/rectal swabs collected between March and May 2011 to determine the regional antibiogram profile. The sample size (ie, 300 isolates tested) was based on the total number of genital GBS isolates per year $(2250$ [15\%]) (ie, recovered from approximately 15,000 vaginal/rectal swabs), a margin of error of $5 \%$ and a CI of $95 \%$. Etest strips were used for the surveillance study to determine the minimum inhibitory concentrations to penicillin, erythromycin and clindamycin according to standard methods (13). All isolates that demonstrated either intermediate or full resistance to erythromycin had a D-test performed to determine inducible resistance to clindamycin (16). The resistance mechanism was inferred from the isolate's individual antibiogram profile. Molecular testing to detect resistance genes was not performed.

\section{RESULTS}

The overall antibiogram pattern derived from our point prevalence study is outlined in Table 1. Although all genital GBS isolates were susceptible to penicillin, there were high rates of resistance to both erythromycin (25\%) and clindamycin (22\%). Most genital GBS isolates that were resistant to erythromycin and clindamycin had a resistance phenotype $\left(\mathrm{MLS}_{\mathrm{B}}\right)$ consistent with the acquisition of a erythromycin ribosomal methylation gene (erm), and most often the resistance was constitutive $\left(\mathrm{MLS}_{\mathrm{B}}-\mathrm{C} ; 14.2 \%\right)$ rather than inducible $\left(\mathrm{MLS}_{\mathrm{B}} \mathrm{-I} ; 8.1 \%\right)$ (Table 1) (16). Erythromycin resistance due to an efflux mechanism (msrA) (3\%) was much less common.

\section{DISCUSSION}

The present study is the first point prevalence study of genital GBS antibiogram profile to be reported from a Canadian health care region. Our data highlight the high rates of resistance to erythromycin (25\%) and clindamycin (22\%) of genital GBS isolates from near-term pregnant women, as has been previously reported recently in other jurisdictions (17-24). In these studies, genital GBS resistance rates for erythromycin ranged from $15 \%$ to $54 \%$ of the strains tested, and slightly lower rates were found for clindamycin resistance. Our results confirm the increasing resistance to both erythromycin and clindamycin worldwide, mainly due to the acquisition and spread of erm genes conveying the $\mathrm{MSL}_{\mathrm{B}}$ phenotype (16). Most commonly, erm genes are constitutively expressed rather than being inducible (positive D-test for clindamycin), similar to the resistance phenotypes recently found in our region $(15,16)$. Erythromycin resistance due to an efflux mechanism ( $\mathrm{msr}$ A) has been reported much less commonly among genital GBS isolates (16).

Our study was prompted by a recent incident of intrapartum prophylaxis failure of erythromycin in a case where both the maternal genital and neonatal blood culture GBS isolates were not susceptible to this drug. Although inadequate prophylaxis may have contributed to the subsequent development of early onset neonatal sepsis in this 
case, inadequate maternal peak serum and fetal tissue levels of erythromycin may have also been a factor. The transplacental transfer of macrolide antibiotics, including erythromycin, has been studied by perfusing term placental tissue after delivery (25). In this study of 21 placentas, erythromycin $(2 \mu \mathrm{g} / \mathrm{mL})$ was given as a $2 \mathrm{~h}$, nonrecirculating perfusion of a single placental cotyledon, and drug concentrations were measured by high-performance liquid chromatography. The mean transplacental transfer of erythromycin was only 3\% when calculated as the ratio between the steady state concentrations in fetal venous and maternal arterial sides, but similar results were obtained for calculations of the absolute amount of drug transferred across the placenta during the $2 \mathrm{~h}$ perfusion (25). Although this was a small study, it suggests that the placenta is an effective barrier that limits transplacental transfer of erythromycin, which may compromise the efficacy of intrapartum prophylaxis with this compound. No clinical trials of intrapartum prophylaxis have been performed using either erythromycin or clindamycin as alternate agents when a $\beta$-lactam cannot be used.

The clinical significance of increasing rates of genital erythromycinresistant GBS isolates is also shown by more recent assessments of the rate of early onset neonatal sepsis. Chen et al (26) performed a timetrend study at a tertiary care centre in the United States over several periods of time including no protocol for group B streptococcus prophylaxis (1990 to 1992), risk-based protocol (1993 to 1996) and a screening-based protocol (1997 to 2002). A total of 120,952 neonates were born during this time with 118 cases of GBS early onset neonatal sepsis. None of the GBS isolates were resistant to ampicillin, penicillin, cefazolin or vancomycin. Although the rate of GBS earlyonset neonatal sepsis decreased significantly across these periods (from 2.0 to 1.1 to 0.4 per 1000 live births, respectively; $\mathrm{P}<0.0001$ ), and the overall rate of erythromycin-resistant GBS neonatal sepsis did not change (from 0.14 to 0.03 to 0.08 per 1000 live births, respectively; $\mathrm{P}=0.60)$, an increasing proportion of cases were due to erythromycin-resistant GBS strains (from $7 \%$ to $2.6 \%$ to $23.8 \%$, respectively; $\mathrm{P}=0.07)(26)$.

The high rates of genital GBS resistance to both erythromycin and clindamycin in our region makes it necessary to modify both current clinical and laboratory practice. Routine antibiotic susceptibility testing must be performed for all GBS isolates recovered from near-term pregnant women who have a reported or documented history of penicillin allergy. Currently, the onus is on the physician to provide the laboratory with a clear clinical history of penicillin allergy for antibiotic susceptibility testing to be performed. However, even with a well-designed laboratory requisition, laboratory orders will sometimes

\section{REFERENCES}

1. Verani JR, L McGee, Schrag SJ. Prevention of perinatal group B streptococcal disease: Revised guidelines from CDC, 2010. Morb Mortal Wkly Rep 2010;59:1-31.

2. Verani JR, Schrag SJ. Group B streptococcal disease in infants: Progress in prevention and continued challenges. Clin Perinatol 2010;37:375-92.

3. Vergnano S, Menson E, Kennea N, et al. Neonatal infections in England: The NeonIN surveillance network. Arch Dis Child Fetal Neonatal Ed 2011;96:F9-14.

4. Hamada S, Vearncombe M, McGeer A, Shah PS. Neonatal group B streptococcal disease: Incidence, presentation, and mortality. J Matern Fetal Neonatal Med 2008;21:53-7.

5. Edwards MS, Baker CJ. Group B streptococcal infections. In: Remington JA, ed. Infectious Diseases of the Fetus and Newborn Infant. Philadelphia: WB Saunders, 2001:1091-156.

6. Stoll BJ, Hansen NI, Sanchez PJ, et al. Early onset neonatal sepsis: The burden of group B Streptococcal and E. coli disease continues. Pediatrics 2011;127:817-26.

7. Davies HD, Adair CE, Partlow ES, Sauve R, Low DE, McGeer A. Two-year survey of Alberta laboratories processing of antenatal group B streptococcal (GBS) screening specimens: Implications for GBS screening programs. Diagn Microbiol Infect Dis 1999;35:169-76.

8. Schrag SJ, Zywicki S, Farley MM, et al. Group B streptococcal disease in the era of intrapartum antibiotic prophylaxis. N Engl J Med 2000;342:15-20. be missed (27). Online order entry with a requirement for penicillin allergy history or a modified laboratory requisition (eg, checkbox should be included) could improve physician ordering and minimize laboratory errors.

The safest way to ensure availability of appropriate antibiotic susceptibility at delivery would be to institute routine antibiotic testing on all genital GBS isolates. Cost estimates, however, indicate this would add $\$ 16.58$ per specimen (approximately $\$ 81,476.84$ per year in our laboratory), mainly due to an increase of a 0.72 full-time equivalent of additional medical laboratory assistant/technologist labour.

Canadian guidelines for the prescription of alternative antibiotic agents for women with penicillin allergy also need to be updated to align with those recently published by the Centers for Disease Control (Atlanta, Georgi, USA) in the United States (1). Penicillin or an equivalent $\beta$-lactam antibiotic (ie, cefazolin, third generation cephalosporin) should remain the drug of choice for prophylaxis of women who do not have a drug allergy. Erythromycin should no longer be used as an alternative antimicrobial agent for intrapartum prophylaxis of pregnant women colonized with GBS, as highlighted by our case. Clindamycin may still be used if the isolate has been confirmed to be susceptible to this agent. However, if the isolate is clindamycin resistant or antibiotic susceptibility testing has not been performed before delivery, then vancomycin should be used instead as the primary alternative agent of choice in penicillin-allergic women. Although vancomycin requires prolonged infusion $(2 \mathrm{~h})$, genital GBS remain universally susceptibile, and the drug's transplacental passage occurs in a predictable manner in concentrations that exceed the usual GBS breakpoint provided an appropriate dose is given based on body weight and renal function $(28,29)$.

A multiregion prevalence study of genital GBS isolate antibiotic susceptibility profiles also needs to be performed to confirm the levels of resistance to erythromycin and clindamycin in other Canadian health care regions. The derived antibiogram profile for genital GBS isolates should then be used to publish new Canadian guidelines for the prevention of neonatal GBS infection that discourages the empirical use of either erythromycin or clindamycin in near-term pregnant women with laboratory-confirmed genital GBS colonization.

ACKNOWLEDGEMENTS: The present study was approved and supported by the Division of Microbiology, Calgary Laboratory Services. The authors thank the supervisory staff, and the medical laboratory technologists who assisted with the present study.

9. Weston EJ, Pondo T, Lewis MM, et al. The burden of invasive early-onset neonatal sepsis in the United States, 2005-2008. Pediatr Infect Dis J 2011;30:937-41.

10. Powers RJ, Wirtschafter D. Prevention of group B Streptococcus early-onset disease: A toolkit by the California Perinatal Quality Care Collaborative. J Perinatol 2010;30:77-87.

11. Illuzzi JL, Bracken MB. Duration of intrapartum prophylaxis for neonatal group B streptococcal disease: A systematic review. Obstet Gynecol 2006;108:1254-65.

12. Money DM, Dobson S. The prevention of early-onset neonatal group $B$ streptococcal disease. J Obstet Gynaecol Can 2004;26:826-40.

13. Clinical Laboratory Standards Institute (CLSI). Performance Standard for Antibiotic Susceptibility Testing; 21st Informational Supplement. M100-S21. Wayne: The Institute, 2011.

14. Church DL, Baxter H, Lloyd T, Miller B, Elsayed S. Evaluation of StrepB carrot broth versus Lim broth for detection of group B Streptococcus colonization status of near-term pregnant women J Clin Microbiol 2008;46:2780-2.

15. Woods CR. Macrolide-inducible resistance to clindamycin and the D-test. Pediatr Infect Dis J 2009;28:1115-8.

16. Leclercq R. Mechanisms of resistance to macrolides and lincosamides: Nature of the resistance elements and their clinical implications. Clin Infect Dis 2002;34:482-92.

17. Balikova D, Adamkova V, Svobodova J. [High resistance of bacterial strains Streptococcus agalactiae to antibiotic therapy in 
early-onset and late-onset disease in newborns]. Ceska Gynekol 2011;76:235-9.

18. DiPersio LP, DiPersio JR. High rates of erythromycin and clindamycin resistance among OBGYN isolates of group B Streptococcus. Diagn Microbiol Infect Dis 2006;54:79-82.

19. Garland SM, Cottrill E, Markowski L, et al. Antimicrobial resistance in group B streptococcus: The Australian experience. J Med Microbiol. 2011;60:230-5.

20. Zhao Z, Kong F, Zeng X, Gidding HF, Morgan J, Gilbert GL. Distribution of genotypes and antibiotic resistance genes among invasive Streptococcus agalactiae (group B streptococcus) isolates from Australasian patients belonging to different age groups. Clin Microbiol Infect 2008;14:260-7.

21. Gygax SE, Schuyler JA, Kimmel LE, Trama JP, Mordechai E, Adelson ME. Erythromycin and clindamycin resistance in group B streptococcal clinical isolates. Antimicrob Agents Chemother 2006;50:1875-7.

22. Clifford V, Heffernan HM, Grimwood K, Garland S. Variation in erythromycin and clindamycin resistance patterns between New Zealand and Australian group B streptococcus isolates.

Aust N Z J Obstet Gynaecol 2011;51:328-32.

23. Pinheiro S, Radhouani H, Coelho C, et al. Prevalence and mechanisms of erythromycin resistance in Streptococcus agalactiae from healthy pregnant women. Microb Drug Resist 2009;15:121-4.
24. Panda B, Iruretagoyena I, Stiller R, Panda A. Antibiotic resistance and penicillin tolerance in ano-vaginal group B streptococci. J Matern Fetal Neonatal Med 2009;22:111-4.

25. Heikkinen T, Laine K, Neuvonen PJ, Ekblad U. The transplacental transfer of the macrolide antibiotics erythromycin, roxithromycin and azithromycin. BJOG 2000;107:770-5.

26. Chen KT, Puopolo KM, Eichenwald EC, Onderdonk AB, Lieberman E. No increase in rates of early-onset neonatal sepsis by antibioticresistant group B Streptococcus in the era of intrapartum antibiotic prophylaxis. Am J Obstet Gynecol 2005;192:1167-71.

27. Valenstein P, Meier F. Outpatient order accuracy. A College of American Pathologists Q-Probes study of requisition order entry accuracy in 660 institutions. Arch Pathol Lab Med 1999;123:1145-50.

28. Laiprasert J, Klein K, Mueller BA, Pearlman MD. Transplacental passage of vancomycin in noninfected term pregnant women. Obstet Gynecol 2007;109:1105-10.

29. Hnat MD, Gainer J, Bawdon RE, Wendel GD Jr. Transplacental passage of vancomycin in the ex vivo human perfusion model. Infect Dis Obstet Gynecol 2004;12:57-61. 


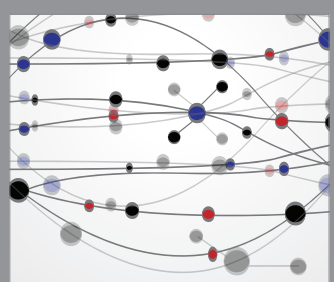

The Scientific World Journal
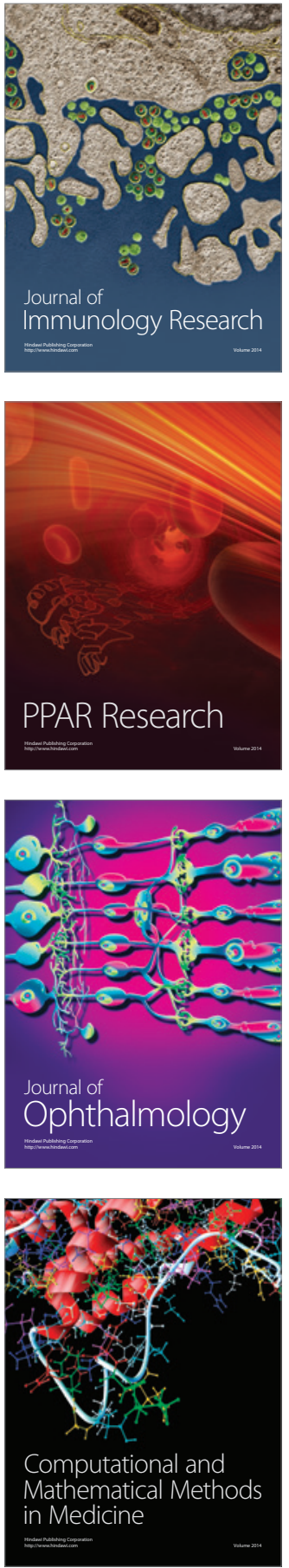

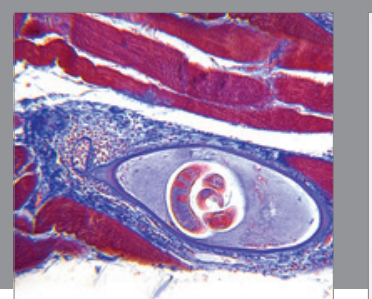

Gastroenterology Research and Practice

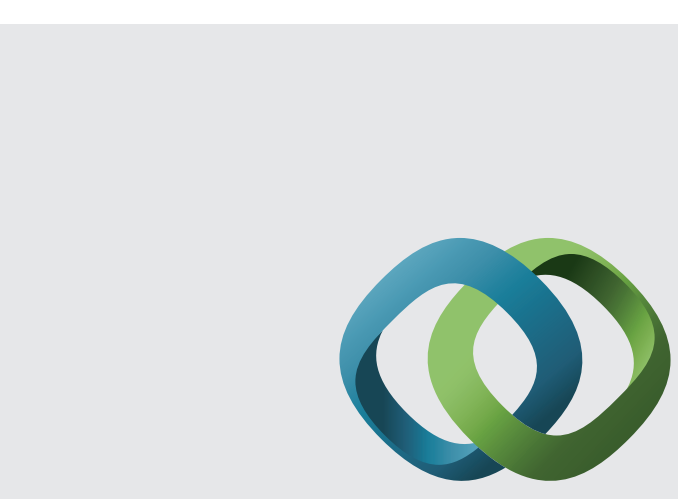

\section{Hindawi}

Submit your manuscripts at

http://www.hindawi.com
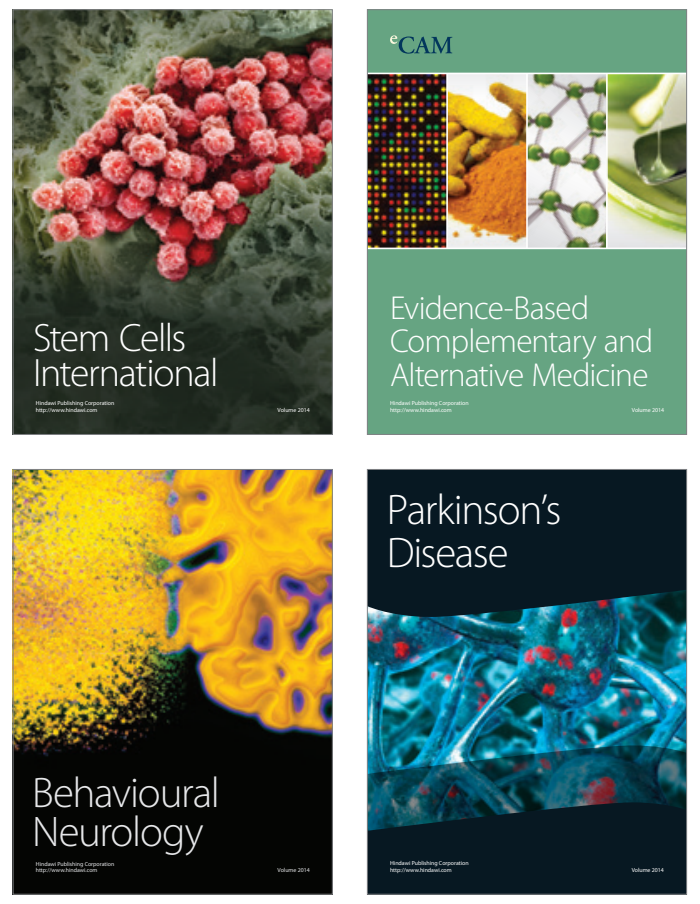
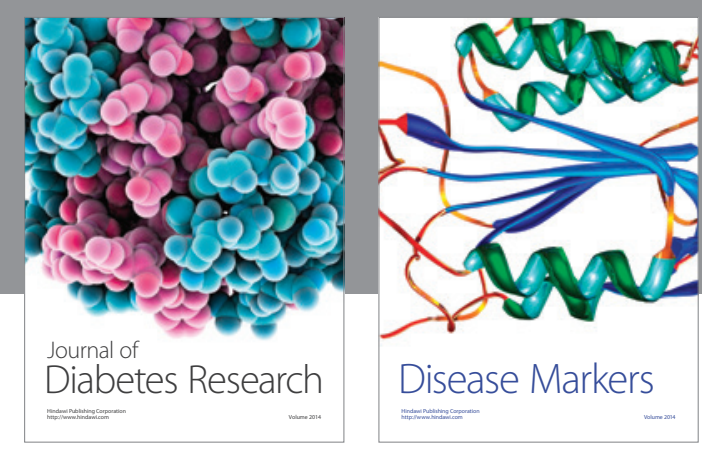

Disease Markers
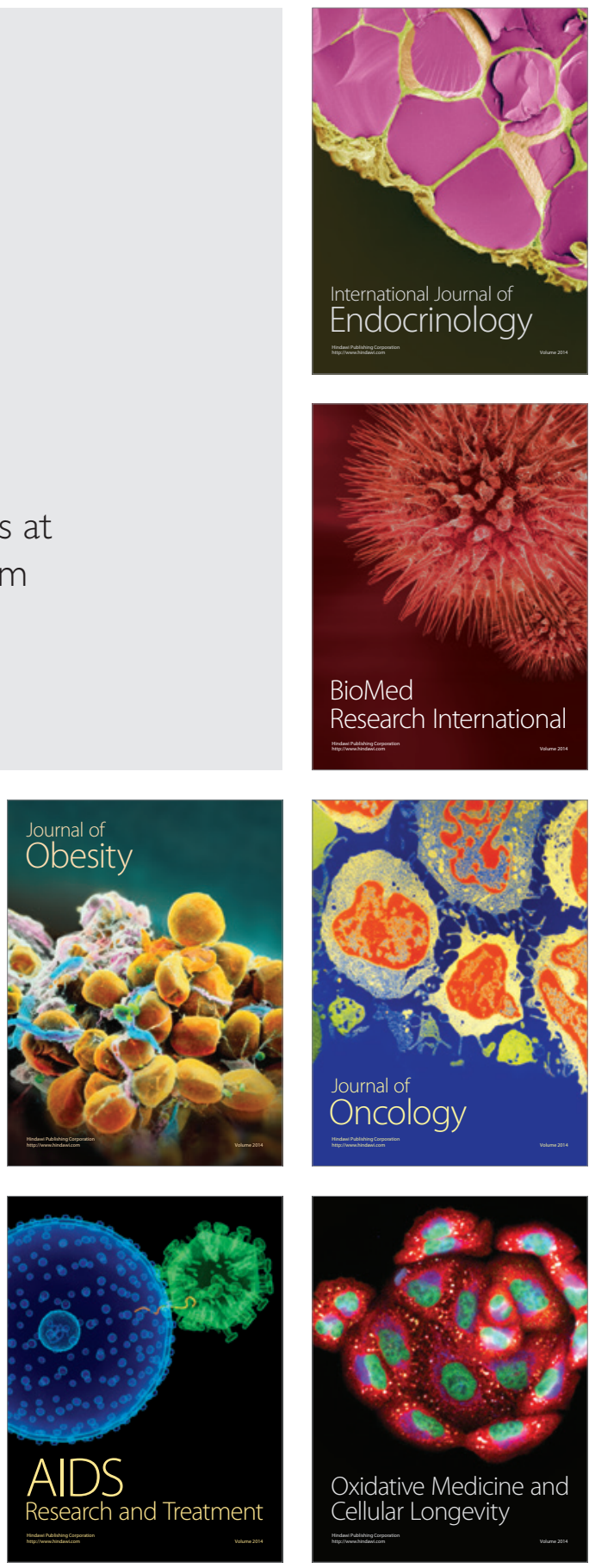